\title{
Сравнение тотальной
}

\section{и частичной тиреоидэктомии при доброкачественном зобе}

ДЛЯ КОРРЕСПОНДЕНЦИИ

Рами А. Хассан - кафедра общей хирургии, медицинский факультет Университета Асьюта (Асьют, Египет)

E-mail: ramyhassan@aun.edu.eg https://orcid.org/0000-0001-9135-

\author{
Фахд Абд Эльрахим Ахмед, Абдалла Бадави Абдалла, Алмоатаз Ахмед \\ Эльтайеб, Рами А. Хассан \\ Медицинский факультет Университета Асьюта, 71516, г. Асьют, Египет
}

Ключевые слова: возвратный гортанный нерв, тиреоидэктомия, многоузловой зоб, случайный рак щитовидной железы
Доброкачественные заболевания щитовидной железы представляют собой сложную хирургическую проблему. При многоузловом зобе применяются несколько хирургических вмешательств: частичная тиреоидэктомия (ST), почти полная тиреоидэктомия (NTT), гемитиреоидэктомия с частичной резекцией (по Данхиллу) и полная тиреоидэктомия (TT). Однако выбор хирургического метода все еще остается дискутабельным. Настоящая работа посвящена сравнению ТT и ST при многоузловом зобе.

Материал и методы. В исследование продолжительностью 3 года были включены 60 пациентов с доброкачественным увеличением щитовидной железы. В исследование не включали пациентов с рецидивирующим, односторонним или злокачественным многоузловым зобом. Пациенты были разделены на 2 группы (по 30 в каждой) в зависимости от типа вмешательства: частичная тиреоидэктомия (ST) в сравнении с полной тиреоидэктомией (TT). Всем пациентам выполняли ультразвуковое исследование (УЗИ) шеи, исследование функции щитовидной железы и тонкоигольную аспирационную биопсию. Пациентов обеих групп оценивали на предмет развития послеоперационных осложнений, а также у них проводили гистопатологическое исследование.

Результаты. Большинство пациентов были женского пола, возраст составил 30-40 лет. Самыми распространенными диагнозами в настоящем исследовании являлись контролируемый токсический вторичный зоб (48,3\%) и простой узловой зоб (41,7\%). Пациенты обеих групп незначительно различались по возрасту, полу, клиническому диагнозу, функции щитовидной железы и данным УзИ. Кроме того, группы не различались по объему кровотечения и частоте раневых инфекций. Распространенность временного/постоянного пареза возвратного гортанного нерва была сравнима в обеих группах: 3,3\% (TT) vs 0 (ST). Распространенность гипопаратиреоза составила $6,7 \%$ в группе ТT и не наблюдалась в группе ST $(p=0,24)$. У 4 пациентов из группы ТT и 6 из группы ST при гистопатологическом исследовании обнаружено злокачественное поражение. У 6 пациентов из группы ST злокачественное новообразование потребовало проведения полной тиреоидэктомии

Заключение. Полная и частичная тиреоидэктомии считаются безопасными и эффективными вмешательствами при доброкачественном заболевании щитовидной железы. Одним из значимых преимуществ полной тиреоидэктомии в сравнении с частичной является отсутствие рецидивов и случайных злокачественных находок при гистопатологии.

Финансирование. Исследование не имело спонсорской поддержки.

Конфликт интересов. Авторы заявляют об отсутствии конфликта интересов.

Для цитирования: Фахд Абд Эльрахим Ахмед, Абдалла Бадави Абдалла, Алмоатаз Ахмед Эльтайеб, Рами А. Хассан. Сравнение тотальной и частичной тиреоидэктомии при доброкачественном зобе // Клиническая и экспериментальная хирургия. Журнал имени академика Б.В. Петровского. 2020. Т. 8, № 4. С. 104-109. D0I: https://doi.org/10.33029/23081198-2020-8-4-104-109

Статья поступила в редакцию 10.10.2020. Принята в печать 18.11.2020. 
Fahd Abd Elraheem Ahmed, Abdallah Badawy Abdallah, Almoataz Ahmed Eltayeb, Ramy A. Hassan

Faculty of Medicine, Assiut University, 71516, Assiut, Egypt

Benign thyroid diseases are challenging for both medical and surgical intervention. There are several surgical methods for thyroidectomy in the case of MNG, such as subtotal thyroidectomy (ST), near-total thyroidectomy (NTT), hemithyroidectomy plus subtotal resection (Dunhill procedure) and total thyroidectomy (TT). However, the surgical method of choice is still controversial. The current work aimed to compare TT and ST in the management of MNG.

Patients and methods. Sixty patients with benign thyroid enlargement were enrolled in the study over a three-year duration. Any patient with recurrent, unilateral, or malignant MNG was excluded. Patients were divided into two groups (30 patients in each one) according to the type of operation performed (total thyroidectomy vs subtotal thyroidectomy). All patients evaluated with neck ultrasound, thyroid function, and fine-needle aspiration. Both groups of patients were assessed for postoperative complications and histopathological examination.

Results. The majority of patients were females, and also, the majority of them were 30-40 years old. The most frequent diagnosis in the current study was controlled secondary toxic goiter $(48.3 \%)$ followed by simple nodular goiter $(41.7 \%)$. Both groups had an insignificant difference regarding age, sex, clinical diagnosis, thyroid function, and ultrasound findings. Also, there was no significant difference as regard bleeding and wound infection. The incidence of transient/ permanent RLN palsy was comparable in both TT and ST groups (3.3\% vs 0 , respectively). Also, the incidence of hypoparathyroidism was $6.7 \%$ in the TT group compared to no patients in the ST group $(p=0.24)$. Four patients in the TT group and six patients in the ST group had malignant features on histopathological examination. For those six patients in the ST group with malignant pathology required completion thyroidectomy.

Conclusion. Total thyroidectomy is considered to be a safe and effective procedure for benign thyroid diseases as subtotal thyroidectomy. Even more, TT has a significant advantage over ST as regards the elimination of recurrence rate and incidental malignant findings on histopathology.

Funding. The study had no sponsor support.

Conflict of interests. The authors declare that they have no conflict of interests.

For citation: Fahd Abd Elraheem Ahmed, Abdallah Badawy Abdallah, Almoataz Ahmed Eltayeb, Ramy A. Hassan. Total versus subtotal thyroidectomy in benign goiter. Clinical and Experimental Surgery. Petrovsky Journal. 2020; 8 (4): 104-9. DOI: https://doi.org/10.33029/2308-1198-2020-8-4-104-109 (in Russian)

Received 10.10.2020. Accepted 18.11.2020.

\section{CORRESPONDENCE}

Ramy A. Hassan - Department of General Surgery, Faculty of Medicine, Assiut University (Assiut, Egypt) E-mail: ramyhassan@aun.edu.eg https://orcid.org/0000-0001-9135 6819

\section{Keywords:}

recurrent laryngeal nerve, thyroidectomy, multinodular goiter, incidental thyroid cancer
$\mathrm{T}$ he incidence of thyroid diseases is variable among the general population. There are two major categories, either benign or malignant thyroid diseases. Multinodular goiter (MNG) is the most frequent endocrine disorder that requires surgical intervention. There are many surgical techniques available for MNG, such as subtotal thyroidectomy (ST), near-total thyroidectomy (NTT), hemithyroidectomy plus subtotal resection (Dunhill procedure), and total thyroidectomy (TT) [1].

For more than a century, ST has been frequently performed with the expectation of taking care of nearly all compressive symptoms and cosmetic concerns associated with an MNG with no postoperative hypothyroidism and major morbidity [1]. Total thyroidectomy is a surgical procedure for the treatment of various thyroid diseases with the removal of all thyroid gland tissue. However, the use of total thyroidectomy procedure is deemed not safe for thyroid [2].

ST has many limitations. Recurrence of MNG was reported in $50 \%$ of cases on long term follow up. The function status of the remnant thyroid tissue is still unpredictable. In addition, a significant percentage of cases with postoperative hypothyroidism requires replacement therapy. In some cases, injury of RLN was reported following ST [3].

Recently, TT has replaced ST as an optimal surgical technique for MNG in the clinical field of the majority of endocrine surgeons, and with good results 
and justification. TT for MNG had many advantages of removal of all tissue with subsequent no risk of recurrence. Also, it can resolve all the compressive symptoms of MNG. Lastly, it eliminates any possibility of incidental thyroid cancer (ITC) [4].

This study aimed to assess the incidence of complications with total (TT) and subtotal thyroidectomy (STT) among patients with benign goiter disease and incidental malignancy in MNG.

\section{Patients and methods}

This prospective study was conducted in the period between November 2016 and December 2019. The study followed the Code of Good Practice and the guidelines of the Declaration of Helsinki, seventh revision, 2013. It was approved by the Medical Ethics Committee of the Faculty of Medicine at Assiut University. Written informed consent was obtained from all participants.

\section{Patients}

All patients with benign thyroid enlargement, either diffuse or nodular, and candidate for surgical treatment, were enrolled in the study. Any patient with malignant, recurrent, or unilateral multinodular goiter was excluded from the study. Sixty patients with benign goiter disease were enrolled in the study. Those patients were divided into two equal groups based on the type of operation, either total (TT Group, $n=30$ ) or subtotal thyroidectomy (ST Group, $n=30$ ).

\section{Preoperative assessment}

All enrolled patients were subjected to detailed history taking and thorough physical evaluation. The baseline level of thyroid-stimulating hormone, T3, $\mathrm{T} 4$, and serum calcium, was recorded. For medicolegal purposes, vocal cord examination with a laryngoscope was done. Thyroid evaluation with ultrasound was done with fine-needle aspiration cytology in the suspicious patient. In the case of huge goiter, plain $\mathrm{X}$-ray was performed, and computed tomography was required in cases with retro-sternal goiter. The preoperative cardiopulmonary assessment was done for all patients.

\section{Operative techniques}

\section{Total extracapsular thyroidectomy}

The surgical technique for each operation was the same. After making an incision in the lower anterior neck and dissecting the subhyoid muscles (without cutting them), the thyroid gland was exposed, and the thyroid capsule was dissected, and the lobe was delivered to the wound after the middle thyroid vein was ligated. In order to preserve the external laryn- geal nerve, the superior thyroid vessels were dissected, ligated, and divided in all patients, as close as possible to the thyroid gland. The recurrent laryngeal nerves have been systematically searched, attempts have been made to identify and preserve the parathyroid glands on each side of the thyroid gland with identification of inferior thyroid artery at both sides with dissection and preservation of its branches to parathyroid glands.

\section{Bilateral subtotal thyroidectomy}

The identification of inferior thyroid artery branches to the thyroid gland was made with its ligation near the capsule. The main trunk of that artery was preserved. A small slice only of posteromedial gland tissue on each side was preserved with suturing its capsule to the pretracheal fascia to confirm homeostasis.

\section{Statistical analysis}

Data were analyzed using the statistical package for the social sciences, version 20 (SPSS Inc., Chicago, $\mathrm{IL}$, USA). Continuous data expressed as mean \pm SD and compared with the Student t-test, while nominal data expressed as frequency (percentage) and compared with $\mathrm{Chi}^{2}$ test or Fisher's exact test. The level of confidence was kept at $95 \%$, and hence, the $p$-value was significant if $<0.05$.

\section{Results}

The majority ( $80 \%$ of TT group and $90 \%$ of ST group) were females. The two groups had insignificant differences regarding age and sex $(P>0.05)$.

\section{Baseline thyroid function and ultrasound findings among enrolled patients (tabl. 1)}

Only one patient of the TT group and five (16.7\%) of the ST group had a toxic pattern of thyroid function while all other patients had a euthyroid pattern. Based on ultrasound findings, the majority of patients ( $96.7 \%$ of TT and $83.3 \%$ of ST groups) had a bilateral multinodular goiter. Diffuse gland enlargement was found in one patient of the TT group and $4(13.3 \%)$ of the ST group. A dominant thyroid nodule was observed in only one patient of the ST group. Both groups had insignificant differences regarding baseline thyroid function and ultrasound findings.

\section{Clinical diagnosis of the enrolled patients (tabl. 1)}

Simple nodular goiter was the diagnosis of 19 patients $(63.3 \%)$ of the TT group and $10(33.3 \%)$ of the ST group. Only one patient of the TT group had a primary toxic goiter. In the ST group, primary toxic goiter, secondary toxic goiter, simple nodular goiter, 
Table 1. Baseline data of patients in studied groups

\begin{tabular}{|l|c|c|c|}
\hline \multirow{2}{*}{\multicolumn{1}{|c|}{ Parameter }} & Type of thyroidectomy & s-value \\
\cline { 2 - 4 } & total $(n=30)$ & $36.3 \pm 9.7$ & 0.125 \\
\hline Age (years) & $40.3 \pm 10.2$ & $3(10 \%)$ & 0.472 \\
Sex & $6(20 \%)$ & $27(90 \%)$ & 0.195 \\
Female & $24(80 \%)$ & $25(83.3 \%)$ & \\
\hline Thyroid function & $29(96.7 \%)$ & $5(16.7 \%)$ & $*$ \\
Euthyroid & $1(3.3 \%)$ & $25(83.3 \%)$ & \\
Hyperthyroid & $29(96.7 \%)$ & $4(13.3 \%)$ & \\
\hline Ultrasound findings & $1(3.3 \%)$ & $1(3.3 \%)$ & \\
Multinodular goiter & 0 & & \\
Diffuse gland enlargement & $1(3.3 \%)$ & $10(33.3 \%)$ & \\
Dominant thyroid nodule & $19(63.3 \%)$ & $15(50 \%)$ & \\
\hline Clinical diagnosis & $10(33.3 \%)$ & $1(3.3 \%)$ & \\
Primary toxic goiter & 0 & & \\
Secondary toxic goiter & & & \\
Simple nodular goiter & & & \\
Dominant toxic nodule & & & \\
\hline
\end{tabular}

Note. Data expressed as frequency (percentage), mean (SD); $p$-value was significant if $<0.05$; * $-p$-value cannot be calculated due to the small number of cases in subgroups

and dominant toxic nodule were found in $4(13.3 \%)$, $10(33.3 \%), 15(50 \%)$, and $1(3.3 \%)$ of the patients, respectively.

\section{Postoperative complications in both groups (tabl. 2)}

Only one patient of TT group and two patients of ST group developed wound infection. Transient and permanent RLN injury occurred in one patient of the TT group compared to none of the ST group. Also, hypoparathyroidism was found in two patients $(6.7 \%)$ of the TT group and none of the ST group. One patient in each group developed postoperative bleeding. There was no significant difference between both groups as regards the development of postoperative complications.

\section{Postoperative histopathological diagnosis}

$4(13.3 \%)$ patients in the TT group had malignant features on the histopathological examination compared to $6(20 \%)$ patients in the ST group $(p=0.488)$. Patients in the ST group with incidental malignancy on pathological evaluation required re-operation (completion thyroidectomy).

\section{Discussion}

Total thyroidectomy (TT) and subtotal thyroidectomy (ST) are the most common surgical procedures used for benign thyroid disorders. The choice of such a procedure aims to eradicate the disease and minimize postoperative complications [5]. Subtotal thyroidectomy was preferred because of the low incidence of postoperative complications but had the disadvantage of a high recurrence rate [6]. Recently, there were many studies suggested that TT has an incidence of complications similar to ST [7]. Currently, no consensus about the safety and effectiveness of TT compared to ST or Dunhill operation has been reported [8]. However, the risks of TT do not overweight the cumulative operative risks for recurrent goiter after ST or near-total thyroidectomy. This evidence is in favor of TT for the treatment of benign MNG [9].

Pappalardo et al. reported a recurrence rate of $14.5 \%$ in patients who received medical treatment after subtotal thyroidectomy and $43 \%$ in patients who did not [10]. The recurrence rate after ST reported in the two most cited meta-analysis ranged from 0 to $50 \%$ [11-13]. Other studies revealed that the mean recurrence rate in ST was $10.0 \%$, and TT was signifi-

Table 2. Postoperative complications in both groups

\begin{tabular}{|c|c|c|c|}
\hline \multirow[t]{2}{*}{ Complication } & \multicolumn{2}{|c|}{ Type of thyroidectomy } & \multirow[t]{2}{*}{$p$-value } \\
\hline & total $(n=30)$ & subtotal $(n=30)$ & \\
\hline $\begin{array}{l}\text { Nerve injury } \\
\text { Transient injury } \\
\text { Permanent injury }\end{array}$ & $\begin{array}{l}1(3.3 \%) \\
1(3.3 \%)\end{array}$ & $\begin{array}{l}0 \\
0 \\
\end{array}$ & 1.000 \\
\hline Hypoparathyroidism & $2(6.7 \%)$ & 0 & 0.492 \\
\hline Bleeding & $1(3.3 \%)$ & $1(3.3 \%)$ & 1.000 \\
\hline Wound infection & $1(3.3 \%)$ & $2(6.7 \%)$ & 1.000 \\
\hline
\end{tabular}

Data expressed as frequency (percentage). $p$-value was significant if $<0.05$. 
cantly better than ST in terms of frequency of recurrence $[9,14]$. Only one longitudinal study reported that the recurrence rate was $(0.3 \%)$ after TT. So, the authors of both meta-analyses stated that TT is the best surgical option for benign multinodular goiter [11]. Another study showed that the recurrence rate tended to increase with time of follow up. It was 8.2\% at five years and doubled (15.5\%) at ten years [9].

Re-operation for thyroid disease recurrence has been associated with a high complication rate as the fibrous tissue disturbs normal anatomical architecture. There was a 10-fold increase in RLN and parathyroid gland injuries [15]. There was also an increase in wound infection and bleeding rates [16].

Another limitation of subtotal thyroidectomy is the malignant potential of thyroid nodules. The occult cancer rate varies between 7-10\% [17]. Castro et al. reported that $5 \%$ of thyroid nodules have malignant characteristics [18]. The most common reason for re-operation (completion thyroidectomy) for benign MNG is an incidental finding of occult malignancy in histopathological examination. Re-operation carries a higher risk of RLN and parathyroid injuries [19]. One of the advantages of TT is avoiding completion thyroidectomy for occult cancer and its related risks [8]. Incidental thyroid cancers have been detected in 3-16.6\% of apparently benign goiters after TT or BST in various studies $[12,20]$. A meta-analysis done by Li showed that the incidence of thyroid cancer was comparable between TT and ST [21]. This is consistent with our study; the incidence of occult malignancy in the histopathological specimens was $16.7 \%$ (10\% after ST vs $6.7 \%$ after TT). All patients in the ST group with occult malignancy required completion thyroidectomy.

The most common complications following thyroidectomy are RLN injury, parathyroid gland injury, and bleeding. Some studies reported a higher incidence of complications after TT [22]; others reported lower risk [23, 24]. However, some other studies reported no significant difference in complications between TT and ST $[5,17]$.

The incidence of temporary RLN injury is (5-11\%) while permanent injury (1-3.5\%) [22]. Based on the analyses of Barczynski and Thomusch, the incidence of permanent RLN injury was $0.8 \%$ after ST, $1.4 \%$ after Dunhill operation, and $2.3 \%$ after TT $[9,25]$. 2 recent meta-analyses revealed that TT is more effective in preventing goiter recurrence than other limited resection while has identical morbidity as regards the potential risk of RLN injury $[11,12]$.

Another study showed the rate of transient and permanent RLN palsy (1.7-0\%, respectively) after both TT and ST [26]. Ozbas et al. revealed that transient/permanent RLN injury (1.9-0\%, respectively) after TT, which even less than that for the ST group (4-1\%) [7]. Ciftci reported no significant difference in the incidence of transient/permanent RLN palsy between TT and ST groups. The risk of RLN injury depends on the extent of thyroid resection (TT vS ST), underlying thyroid pathology, and volume of surgeon experience [5]. In the current study, there was only one patient with transient RLN injury and another one with permanent injury after TT compared to none after ST. In agreement with previous studies, there was no significant difference between both groups in incidence of RLN injury ( $p=1.000)$.

The incidence of temporary hypoparathyroidism is $(20-30 \%)$ while permanent in $(1-4 \%)$ [22]. Permanent hypocalcemia results from unintentional removal of parathyroid glands or disruption of the blood supply of parathyroid glands. A large multicenter study included 5195 patients who underwent thyroid resection in 45 hospitals presented significantly higher rates of RLN palsy and hypoparathyroidism following TT than those after ST [22]. Tezelman reported an incidence of transient/persistent hypocalcemia of $8.4-0.8 \%$ after TT and $1.4-0.4 \%$ after ST [20]. Another study reported an incidence of transient/persistent hypocalcemia of $15.1-0.4 \%$ after TT and of 17.5-0\% after ST. There was no significant difference between both groups in the incidence of transient and permanent hypocalcemia [5]. This was consistent with our study, which revealed no significant difference between both groups $(p=0.492)$ regarding developing hypoparathyroidism.

According to the literature, the frequency of postoperative hemorrhage and wound infection ranges between 0 and $2 \%$ [20]. In the study by $0 z$ ba, the hemorrhage rate was $0.4 \%$ after TT and $0 \%$ after ST, and the wound site infection rate was $0 \%$ after TT and $0.6 \%$ after BST [7]. In the current study, there was no significant difference between TT and ST group as regards the incidence of hemorrhage and wound infection ( $p=1.000)$. In agreement with our study, Ciftci et al. also reported the same result in both groups [5].

According to our study, there was no significant difference between 2 groups as regard age, sex, thyroid function, ultrasound findings, and clinical diagnosis. Analysis of the data from all operations performed by one of three highly experienced surgeons demonstrated a low complication rate following total thyroidectomy, more or less identical to those following subtotal procedures [9]. Also, Padur et al. revealed that TT as safe and effective as ST for most of the thyroid diseases [27].

Based on the above evidence, we would conclude from our study that total thyroidectomy is a safe and effective procedure for benign thyroid diseases as subtotal thyroidectomy. Furthermore, ST is associated with a high recurrence rate and leaving behind foci of occult malignancy, which required completion thyroidectomy with its related risks. So, we consider that TT has a significant advantage over ST, especially in the hands of expert surgeons. 


\section{References}

1. Delbridge L. Total thyroidectomy: the evolution of surgical technique. Aust N Z J Surg. 2003; 73 (9): 761-8.

2. Al Saiegh A.M. Correlation between types of thyroid surgery, goitre pathology, and recurrent laryngeal nerve injury-retrospective cohort study. J Surg Res. 2020; 3: 86-95.

3. Parsa A.A., Gharib H. Update on thyroid nodule management. US Endocrinology. 2019; 15 (1): 32-8. DOI: https://doi.org/10.17925/USE.2019.15.1.32

4. Yuksekdag S., Topcu A., Deveci I., Unal E. Recurrent laryngeal nerve injury in total thyroidectomy with intraoperative nerve monitoring and harmonic sealing instrument: A retrospective analysis and treatment results. Eastern J Med. 2019; 24 (2): 210-4 DOI: https://doi. org/10.5505/ejm.2019.33254

5. Ciftci F., Sakalli E., Abdurrahman I. Total versus bilateral subtotal thyroidectomy for benign multinodular goiter. Int J Clin Exp Med. 2015; 8 (3): 4596-600.

6. Bononi M., de Cesare A., Atella F., et al. Surgical treatment of multinodular goiter: incidence of lesions of the recurrent nerves after total thyroidectomy. Int Surg. 2000; 85 (3): 190-3.

7. Ozbas S., Kocak S., Aydintug S., Cakmak A., Demirkiran M.A., Wishart G.C. Comparison of the complications of subtotal, near-total and total thyroidectomy in the surgical management of multinodular goitre. Endocr J. 2005; 52 (2): 199-205.

8. Cirocchi R., Trastulli S., Randolph J., et al. Total or near-total thyroidectomy versus subtotal thyroidectomy for multinodular non-toxic goitre in adults. Cochrane Database Syst Rev. 2015; 8 : CD010370.

9. Barczyński M., Konturek A., HubalewskaDydejczyk A., Gołkowski F., Nowak W. Ten-year follow-up of a randomized clinical trial of total thyroidectomy versus Dunhill operation versus bilateral subtotal thyroidectomy for multinodular non-toxic goiter. World J Surg. 2018; 42 (2): 384-92.

10. Pappalardo G., Guadalaxara A., Frattaroli F.M. Illomei G., Falaschi P. Total compared with subtotal thyroidectomy in benign nodular disease: personal series and review of published reports. Eur J Surg. 1998; 164 (7): 501-6.

11. Moalem J., Suh I., Duh Q.Y. Treatment and prevention of recurrence of multinodular goiter: an evidencebased review of the literature. World J Surg. 2008; 32 (7): 1301-12.

12. Agarwal G., Aggarwal V. Is total thyroidectomy the surgical procedure of choice for benign multinodular goiter? An evidence-based review. World J Surg. 2008; 32 (7): 1313-24.

13. Rayes N., Seehofer D., Neuhaus P. The surgical treatment of bilateral benign nodular goiter - balancing invasiveness with complications. Dtsch Arztebl Int. 2014; 111 (10): 171-8. DOI: https://doi.org/10.3238/ arztebl.2014.0171
14. Yang W., Shao T., Ding J., et al. The feasibility of total or near-total bilateral thyroidectomy for the treatment of bilateral multinodular goiter. J Investig Surg. 2009; 22 (3): 195-200.

15. Reeve T.S., Delbridge L., Brady P., et al. Secondary thyroidectomy: a twenty-year experience. World J Surg. 1988; 12: 449-52. DOI: https://doi.org/10.1007/ BF01655417

16. Müller P.E., Kabus S., Robens E., Spelsberg F. Indications, risks, and acceptance of total thyroidectomy for multinodular benign goiter. Surg Today. 2001; 31 (11): 958-62.

17. Delbridge L., Guinea A.I., Reeve T.S. Total thyroidectomy for bilateral benign multinodular goiter: Effect of changing practice. Arch Surg. 1999; 134 (12): 1389-93.

18. Castro M.R., Gharib H. Thyroid nodules and cancer. Postgrad Med. 2000; 107 (1): 113-24. DOI: https:// doi.org/10.3810/pgm.2000.01.808

19. Glockzin G., Hornung M., Kienle K., et al. Completion thyroidectomy: effect of timing on clinical complications and oncologic outcome in patients with differentiated thyroid cancer. World J Surg. 2012; 36 (5): 1168-73.

20. Tezelman S., Borucu I., Senyurek Y., Tunca F., Terzioglu T. The change in surgical practice from subtotal to near-total or total thyroidectomy in the treatment of patients with benign multinodular goiter. World J Surg. 2009; 33 (3): 400-5.

21. Li Y., Li Y., Zhou X. Total thyroidectomy versus bilateral subtotal thyroidectomy for bilateral multinodular nontoxic goiter: a meta-analysis. ORL J Otorhinolaryngol Relat Spec. 2016; 78 (3): 167-75.

22. Thomusch O., Machens A., Sekulla C., et al. Multivariate analysis of risk factors for postoperative complications in benign goiter surgery: prospective multicenter study in Germany. World J Surg. 2000; 24 (11): 1335-41.

23. Gough I.R., Wilkinson D. Total thyroidectomy for management of thyroid disease. World J Surg. 2000; 24 (8): 962-5

24. Pattou F., Combemale F., Fabre S., et al. hypocalcemia following thyroid surgery: incidence and prediction of outcome. World J Surg. 1998; 22 (7): 718-24.

25. Thomusch O., Machens A., Sekulla C., Ukkat J., Brauckhoff M., Dralle H. The impact of surgical technique on postoperative hypoparathyroidism in bilateral thyroid surgery: a multivariate analysis of 5846 consecutive patients. Surgery. 2003; 133 (2): 180-5.

26. Koyuncu A., Dökmetaş H.S., Turan M., et al. Comparison of different thyroidectomy techniques for benign thyroid disease. Endocr J. 2003; 50 (6): 723-7.

27. Padur A.A., Kumar N., Guru A., et al. Safety and effectiveness of total thyroidectomy and its comparison with subtotal thyroidectomy and other thyroid surgeries: a systematic review. J Thyroid Res. 2016; 2016: 7594615 